\title{
Beyond Bangladesh, OECD countries must act to save lives in the garment industry
}

Written by: Lucy Crehan: "Cleverlands: Lessons from top performing education systems"

Last update: 2 March 2020

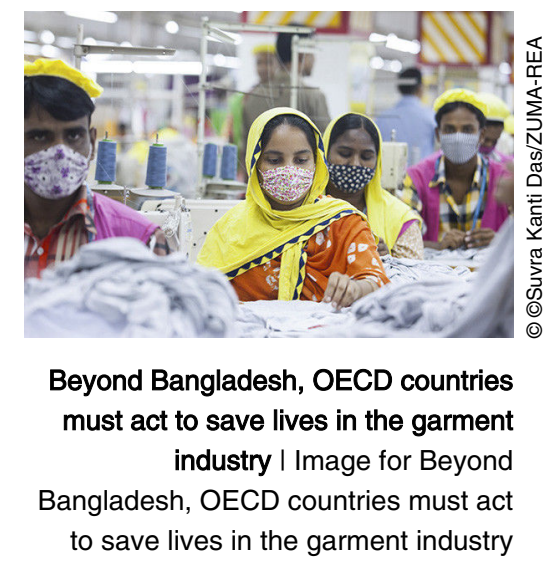

On 24 April 2013, the world woke up to the reality of garment factory conditions in Bangladesh when more than a thousand workers were killed and over two thousand injured after the Rana Plaza garment factory complex, supplying western brands, collapsed.

A bloody line had been crossed. People in countries around the world began caring who made their clothes, and how. Having dismissed warning after warning, global apparel brands could no longer ignore the dangerous working conditions at their supplier factories. Self-regulated safety audits were exposed as shams.

Global unions, IndustriALL and UNI, seized the moment and produced the Bangladesh Accord on Fire and Building, an unprecedented, independent, legally binding agreement between trade unions and brands. The goal: that no worker need fear fires, building collapses, or other accidents that could be prevented with reasonable health and safety measures. It meant that brands had to take responsibility for making their supplier factories safe, and pay towards it too.

1 www.oecdobserver.org I Beyond Bangladesh, OECD countries must act to save lives in the garment industry 
Expert fire and building safety engineers working for the Bangladesh Accord have since inspected more than 1,600 factories making garments for over 200 brands and retailers. Initial inspections identified 118,500 fire, electrical and structural hazards of which $84 \%$ have been corrected. The Accord training team has conducted 2,838 safety committee training sessions with workers at over 1,000 factories.

The Bangladesh Accord works because it has teeth. Two international brands that failed to meet their legal commitments have been successfully taken to the Permanent Court of Arbitration in The Hague. This has led to millions of dollars in reparations being used to remedy life-threatening hazards at the brands' supplier factories. A further US $\$ 300,000$ has been paid into a fund to support IndustriALL and UNI's work to improve pay and conditions for workers in global supply chains.

Five years on, the Bangladesh Accord stands as a model for industrial relations, and shows that brands and unions can work together to solve systemic problems. The Bangladeshi ready-made garment industry is undoubtedly safer, and lives have been saved.

However, the work of the accord, which expired at the end of May 2018, is not complete. Too many life-threatening hazards at supplier factories remain, which is why more than 180 brands (and counting) have signed the new 2018 Transition Accord, which already covers approximately 2 million garment workers in Bangladesh, most of whom are women.

The 2018 accord has greater scope to cover home textiles and footwear and, crucially, gives more power to workers. The new agreement meets OECD Due Diligence Guidance for Responsible Supply Chains in the Garment and Footwear Sector, recognising that workers are not peripheral to the due diligence process, but core to it. It upholds the importance of freedom of association in ensuring workers have a genuine say in protecting their own safety. It will also establish a training and complaints protocol to ensure that this right is respected.

Without labour rights, the gains made in health and safety will not be maintained. Severe anti-union violence and discrimination continues in Bangladesh making it very often impossible for workers to organise and bargain collectively.

OECD countries must use their voice to condemn the attacks on workers and trade unions in Bangladesh. OECD member countries promise to uphold fundamental labour rights and sign up to guidelines to commit multinational enterprises to take responsibility for workers in their global supply chains. This must also include working with trade unions on a national or sector-wide level to achieve wages that, at the very least, meet the basic needs of workers and their families.

The EU, as Bangladesh's biggest trading partner, also has a major role to play. Bangladesh benefits from preferential trade tariffs under the EU's Generalised

2 www.oecdobserver.org I Beyond Bangladesh, OECD countries must act to save lives in the garment industry 
System of Preferences. In turn, Bangladesh is expected to put into practice key UN human rights and International Labour Organization conventions. This is clearly not happening and yet Bangladesh is given chance after chance to put matters right. OECD countries, many of which are also members of the EU, cannot turn a blind eye to these violations. They must speak up.

The Bangladesh Accord will continue its work until 2021, or until the Bangladesh government is ready to take over its functions.

We have the tools to make a better garment industry. We must use them. Public pressure to improve the working conditions of garment workers has never been greater, and now is the time to push for change. The lives of garment workers in Bangladesh and in many places beyond depend on it.

@OECD Observer August 2018

\section{References}

http://bangladeshaccord.org/ http://bangladeshaccord.org/

OECD (2018), OECD Due Diligence Guidance for Responsible Supply Chains in the Garment and Footwear Sector, OECD Publishing, Paris, http://dx.doi.org/ https://doi.org/10.1787/9789264290587-en 